\title{
Evaluation of medical school students' knowledge, attitudes, and behaviors regarding traditional and complementary medicine
}

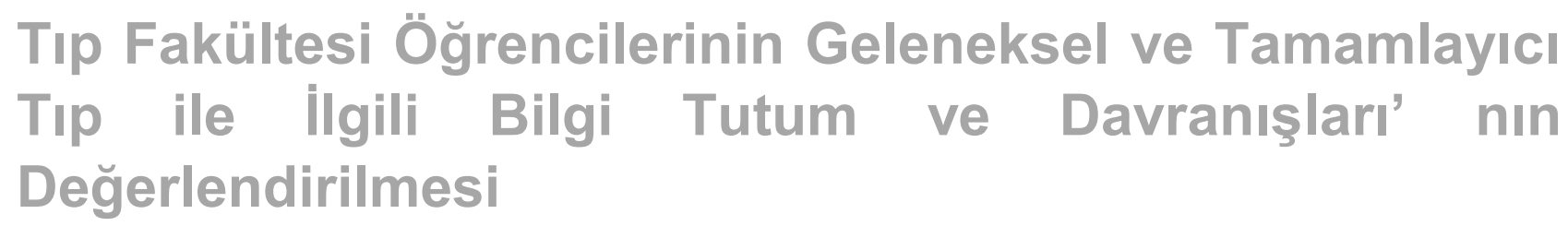

\author{
Seher Karahan, Ezgi Ağadayı, Naim Karago̊z
}

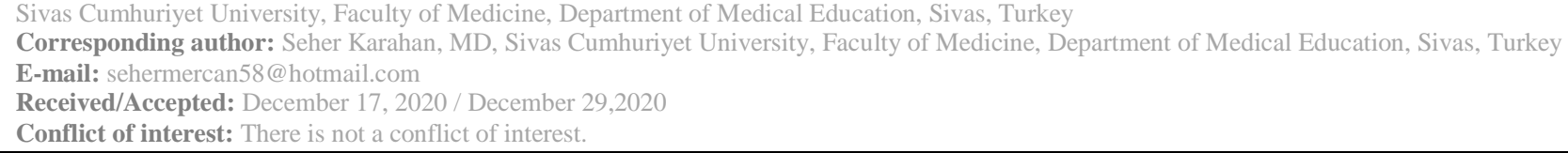

\section{SUMMARY}

Objective: The use of traditional and complementary medicine (TCM) methods in our country in relation to our cultural background increases day by day. For this reason, it is important to raise awareness among medical faculty students, who are future physicians, regarding TCM. Our goal in this study is to evaluate the knowledge, attitude, and behavior of Sivas Cumhuriyet University Faculty of Medicine (SCUFM) students regarding TCM practices.

Method: This descriptive, cross-sectional study was carried out with those who accepted to participate in the study among the $1 \mathrm{st}$, 2nd, 3rd, 4th, 5th, and 6th grade students studying at SCUFM between September 2020 and December 2020. 320 students who volunteered to participate in the study filled out the research questionnaire online.

Results: When the knowledge level of the medical school students participating in our study regarding TCM methods was examined, the most widely known methods were found to be hypnosis treatment $(93.4 \%)$, acupuncture $(93.2 \%)$, and cupping (80\%), respectively. While $19.1 \%$ of the students had a TCM procedure before, the most used methods were cupping $(83.6 \%)$ and leech $(16.4 \%)$ therapy. While $95.6 \%$ of medical students thought that patients should consult their physicians before having any TCM method applied, only $11.6 \%$ thought that TCM methods had only a placebo effect. The $79.1 \%$ of the students, think that there should be courses on TCM methods in medical education.

Conclusions: In our study, we found that medical school students' knowledge on TCM applications is insufficient and they want courses related to TCM to be included in medical education. We believe that by increasing the awareness and knowledge of medical students, who will be the health professionals of the future, about TCM in medical education, these practices can be used more beneficially and in a way that is based on evidence.

Keywords: Traditional and complementary medicine, medical steudent, knowledge
Seher Karahan

Ezgi Ağadayı

Naim Karagöz

ORCID IDs of the authors:

S.K. 0000-0002-4066-2928

E.A. 0000-0001-9546-2483

N.K. 0000-0002-6456-1128 
Amaç: Ülkemizde kültürel geçmişimizle de ilgili olarak GETAT yöntemlerinin kullanımı her geçen gün artmaktadır. Bu nedenle geleceğin hekimleri olan tıp fakültesi öğrencilerinin GETAT ile farkındalıklarının oluşması önemlidir. Biz de bu çalışmamızda SCÜTF ögrencilerinin GETAT uygulamaları hakkındaki bilgi, tutum ve davranışlarını değerlendirmeyi amaçladık.

Yöntem: Tanımlayıcı, kesitsel nitelikte olan bu çalışma Eylül 2020-Aralık 2020 tarihleri arasında Sivas Cumhuriyet Üniversitesi Tip Fakültesinde (SCÜTF) okuyan dönem I, II, III, IV, V ve VI öğrencilerinden çalışmaya katılmayı kabul edenlere uygulanmıştır. Çalışmaya katılmaya gönüllü olan 320 öğrenciye 24 sorudan oluşan çalışma anketi online olarak uygulanmıştır.

Bulgular: Çalışmamıza katılan tıp fakültesi öğrencilerinin GETAT yöntemlerini bilme durumları incelendiğinde, en yüksek oranda bilinen yöntemler sirasıly hipnoz tedavisi $(\% 93,4)$, akupunktur $(\% 93,2)$ ve kupa uygulaması $(\% 80)$ olarak tespit edildi. Öğrencilerin \%19,1'i daha önceden herhangi bir GETAT yöntemi kullanmış olup, en çok kullandıkları yöntem kupa $(\% 83,6)$ ve sülük $(\% 16,4)$ tedavisiydi. T1p öğrencilerinin $\% 95,6$ 's1 herhangi bir GETAT yöntemi uygulatmadan önce hastaların hekimlere danışması gerektiğini düşünürken yalnızca \%11,6'sı GETAT yöntemlerinin sadece plasebo etkisi olduğunu düşünüyordu. Öğrencilerin büyük çoğunluğu \%79,1’i tip eğitiminde GETAT yöntemleri ile ilgili dersler olması gerektiğini düşünüyordu.

Sonuç: Çalışmamızda tıp fakültesi öğrencilerinin GETAT uygulamaları ile ilgili bilgi düzeylerinin yetersiz olduğunu ve GETAT ile ilgili derslerin tıp eğitiminde olmasını istediklerini saptadık. Geleceğin sağlık profesyonelleri olacak olan tıp öğrencilerinin GETAT ile ilgili farkındalıklarını ve bilgi düzeylerini tıp eğitimi içerisinde artırmanın bu uygulamaların kanıta dayalı şekilde daha faydalı kullanılabileceği kanaatindeyiz.

Anahtar sözcükler: Geleneksel ve Tamamlayıc1 Tip, Tıp Öğrencisi, Bilgi

\section{INTRODUCTION}

Definition of traditional and complementary medicine (TCM) according to the World Health Organization (WHO) is: "The set of knowledge, skills, and practices-based on theories, beliefs, and experiences specific to different cultures, which can or cannot be explained- that are used in prevention, diagnosis, improvement or treatment of physical and mental diseases, as well as maintaining good health" 1 .

These practices have a long history. In direct proportion to the increasing life expectancy of people, chronic and malignant diseases are also increasing. For reasons such as healthcare professionals not being able to allocate sufficient time to their patients and wanting to avoid the side effects of medications, patients' interest in traditional and complementary medicine methods has increased. It is predicted that the use of these methods will increase in time ${ }^{2}$. To protect people from the harmful effects of these methods and to prevent their unauthorized use, various measures have been taken in Turkey and in the world. For this purpose, "Regulation on Traditional and Complementary Medicine Practices" has been issued in Turkey on October 27, 2014. In this regulation, 15 methods have been accepted and their usage areas have been stated. These are phytotherapy, mesotherapy, larval therapy, prolotherapy, cupping, music therapy, hypnotherapy, homeopathy, leech therapy, ozone therapy, osteopathy, reflexology, acupuncture, apitherapy, chiropractic ${ }^{3}$.
Authorization to use these methods is given to doctors, and dentists and pharmacists, provided that they do not go beyond their own field. Public and private health institutions were named 'application units,' university hospitals and training and research hospitals were named 'application center.' It was decided that training can only be given in application centers, provided that the approval of Ministry of Health is obtained ${ }^{3,4,5}$.

The use of TCM methods in our country in relation to our cultural background increases day by day. For this reason, it is important to raise awareness among medical faculty students, who are future physicians, regarding TCM. Our goal in this study is to evaluate the knowledge, attitude, and behavior of medical students regarding TCM practices.

\section{MATERIAL AND METHODS}

\section{Design}

This is a descriptive study conducted at Sivas Cumhuriyet University Faculty of Medicine (SCUFM).

\section{Participants}

All of 1371 students, during the 2019-2020 academic year, at SCUFM were included in the study.

\section{Data Collection}

After obtaining the relevant medical faculty permission to carry out the study, the information about the study and the online survey link were sent to all students via e-mail. Sample selection was not made. An attempt was made to reach all students. Participation in the study was voluntary. The first 
e-mail was sent on 01.08.2020 and online survey link was closed on 01.11.2020. A reminder mail was sent to the students at regular intervals (fortnightly).

\section{Measurement}

The data collection tool we applied for the study consists of 24 items; the demographic data of the students were questioned in the first 7 items. The remaining 17 items are questions that measure the level of knowledge about TCM methods and attitudes and behavior regarding these methods recognized by the Ministry of Health within the scope of the TCM applications regulation. These methods are 1. phytotherapy, 2. mesotherapy, 3. larval therapy, 4. prolotherapy, 5. cupping, 6. music therapy, 7. hypnotherapy, 8 . homeopathy, 9. leech therapy, 10. ozone therapy, 11. osteopathy, 12. reflexology, 13. acupuncture, 14. apitherapy, 15. chiropractic. With these questions, their knowledge level about the TCM practices specified in the regulation issued by Ministry of Health, whether they or any member of their family used any of these methods before, the source from which they obtained their knowledge about TCM, and their opinions about the effectiveness of TCM methods were questioned.

\section{Ethical Approval}

The ethics committee of the Sivas Cumhuriyet University Non-Interventional Clinical Research approved this protocol (Approval number: E202003/42).

\section{Statistics}

Collected data analyzed with a statistics software package (SPSS for Windows, Version 25.0). The results are summarized as percentages for categorical variables. Chi-square test was used to analyze the categorical data.
Students were grouped according to their grade level; 1st, 2nd, and 3rd grade students as studying basic sciences, and 4th, 5th, and 6th grade students as studying clinical sciences. The place where they made the TMC methods and the class (clinical/basic) they studied was compared. It was thought that there would be a difference in this regard due to the better clinical knowledge of those studying in the clinic.

A p-value of less than 0.05 was considered for statistical significance, with a $95 \%$ confidence interval.

\section{RESULTS}

320 students volunteered to participate in the study. Response rate was $23.3 \%$. 64.1\% $(n=205)$ of the participants were female and $35.9 \%(n=115)$ were male. $63.1 \%(n=202)$ of them were studying basic sciences and $36.9 \%(\mathrm{n}=118)$ were studying clinical sciences.

The education level of the mothers of the participants was $46.0 \%(\mathrm{n}=145)$ primary school, $25.7 \%(\mathrm{n}=81)$ high school, $28.3 \%$ ( $\mathrm{n}=89$ ) bachelorgraduate school level. The education level of their fathers was $21.2 \%(\mathrm{n}=66)$ primary school, $27.2 \%$ $(\mathrm{n}=85)$ high school, 51.6\% $(\mathrm{n}=161)$ bachelorgraduate school level.

When the knowledge level of students regarding TCM was examined, the most widely known methods were found to be hypnosis treatment (93.4\%), acupuncture (93.2\%), and cupping (80\%), respectively. The least known TCM methods by the students were prolotherapy (97.2\%), reflexology (95.3\%), hirudotherapy (93.8\%), and apitherapy (90\%). In Table 1, students' knowledge level of TCM methods and information on whether they or one of their first-degree relatives have used any of these methods before are given. 
Table 1: Students' knowledge of traditional and complementary medicine methods, usage status and use of their relatives

\begin{tabular}{|c|c|c|c|c|c|c|}
\hline & \multicolumn{2}{|c|}{ Knowledge status } & \multicolumn{2}{|c|}{ Using status } & \multicolumn{2}{|c|}{$\begin{array}{c}\text { Using of first degree } \\
\text { relatives }\end{array}$} \\
\hline & $\mathrm{n}$ & percent & $\mathrm{n}$ & percent & $\mathrm{n}$ & percent \\
\hline Acupuncture & 298 & 93.2 & 5 & 1.6 & 19 & 5.9 \\
\hline Apitherapy & 32 & 10 & 0 & 0 & 0 & 0 \\
\hline Phytotherapy & 129 & 40.3 & 1 & 0.3 & 7 & 2.1 \\
\hline Homeopathy & 53 & 16.6 & 1 & 0.3 & 0 & 0 \\
\hline Cupping & 256 & 80 & 51 & 15.9 & 114 & 35.6 \\
\hline Mesotherapy & 74 & 23.2 & 0 & 0 & 1 & 0.3 \\
\hline Osteopathy & 55 & 17.2 & 1 & 0.3 & 1 & 0.3 \\
\hline Prolotherapy & 9 & 2.8 & 0 & 0 & 0 & 0 \\
\hline Ozone & 74 & 23.2 & 0 & 0 & 1 & 0.3 \\
\hline Hirudotherapy & 20 & 6.3 & 10 & 3.1 & 6 & 1.8 \\
\hline Hypnosis & 299 & 93.4 & 1 & 0.3 & 1 & 0.3 \\
\hline Larvae Treatment & 43 & 13.5 & 0 & 0 & 0 & 0 \\
\hline Reflexology & 15 & 4.7 & 0 & 0 & 0 & 0 \\
\hline Music therapy & 249 & 77.8 & 0 & 0 & 0 & 0 \\
\hline Chiropractic & 65 & 20.3 & 0 & 0 & 0 & 0 \\
\hline
\end{tabular}

$19.1 \%(\mathrm{n}=61)$ of the participants had at least one TCM procedure before. The TCM procedures these participants had are, in order of frequency, cupping $(\mathrm{n}=51 ; 83.6 \%)$, leech therapy $(\mathrm{n}=10 ; 16.4 \%)$, acupuncture $(\mathrm{n}=5 ; 8.2 \%)$, phytotherapy $(\mathrm{n}=1$; $1.6 \%)$, hypnosis therapy $(\mathrm{n}=1 ; 1.6 \%)$, homeopathy $(\mathrm{n}=1 ; 1.6 \%)$, and osteopathy $(\mathrm{n}=1 ; 1.6 \%)$. The reasons for having these procedures are, in order of frequency, muscle pain $(n=28 ; 45.9 \%)$, common cold/flu $(\mathrm{n}=11 ; 18.0 \%)$, stress $(\mathrm{n}=11 ; 18.0 \%)$, complementary therapy for chronic illness $(n=2$; $3.3 \%)$, to lose weight $(\mathrm{n}=1 ; 1.6 \%)$, for cosmetic purposes $(n=1 ; 1.6 \%)$. $77.0 \% \quad(n=47)$ of the participants that had one of these procedures benefited from it, while $16.4 \% \quad(n=10)$ stated neither benefit nor harm, and $6.6 \%(n=4)$ said they were harmed. Complications had developed in 3 of those who were harmed, and the symptom had worsened in 1 of them. Of those who had a TCM procedure, $8.2 \%(\mathrm{n}=5)$ had it at a hospital, $77.0 \%$ $(n=47)$ at home, $11.5 \%(n=7)$ at a doctor's office, $30.3 \%(n=20)$ at a non-physician's office. The frequency of those whose first-degree relatives had a TCM procedure was $44.4 \%(n=142)$.

There was a statistically significant difference between gender and having had a TCM procedure $(\mathrm{p}=0.045) \cdot 16.1 \% \quad(\mathrm{n}=33)$ of women and $24.3 \%$ $(n=28)$ of men had previously had a TCM procedure. No statistically significant difference was found between the education level of their mother/father and having had a TCM procedure $(\mathrm{p}=0.169 ; \mathrm{p}=0.125$, respectively). No statistically significant difference was found between gender and having the TCM procedure at the hospital, at home, at the doctor's office, and at a nonphysician's office $(\mathrm{p}=0.130 ; \mathrm{p}=0.287 ; \mathrm{p}=0.287$; $\mathrm{p}=0.051$, respectively). A statistically significant difference was found between having the TCM 
procedure at the hospital and studying basic sciences or clinical sciences $(p=0.007)$. All of the students who had the procedure at a hospital were studying clinical sciences $(100 \% ; n=5)$. No statistically significant differences were found between studying basic-clinical sciences and having the procedure at home, at the doctor's office, or at a non-physician's office ( $\mathrm{p}=0.163 ; \mathrm{p}=0.199$; $\mathrm{p}=0.542$, respectively).

The sources from which they obtained information about TCM are, in order of frequency, Internet (33.4\%; $\mathrm{n}=107)$, family $(22.5 \% ; \mathrm{n}=72)$, friends
$(17.2 \% ; \mathrm{n}=55)$, television $(7.8 \% ; \mathrm{n}=25)$, healthcare worker $(4.7 \% ; \mathrm{n}=15)$, and medical education $(0.9 \% ; n=3)$. Students' opinions about the benefit of TCM methods are given in Table 2.

While $95.6 \%$ of the medical school students think that physicians should be consulted before having any TCM procedure, only $11.6 \%$ think that TCM methods only have a placebo effect. The $79.1 \%$ of the students, think that there should be courses on TCM methods in medical education. The responses of the students to the statements about TCM are given in Table 3.

Table 2: Opinions about the usefulness of traditional and complementary medicine methods

\begin{tabular}{|c|c|c|c|}
\hline & Beneficial & No idea & Useless \\
\hline Acupuncture & $161(50.3 \%)$ & $155(48.4 \%)$ & $4(1.3 \%)$ \\
\hline Apitherapy & $10(3.1 \%)$ & $307(95.9 \%)$ & $3(0.9 \%)$ \\
\hline Phytotherapy & $41(12.8 \%)$ & $277(86.6 \%)$ & $2(0.6 \%)$ \\
\hline Homeopathy & $12(3.8 \%)$ & $305(95.3 \%)$ & $3(0.9 \%)$ \\
\hline Cupping & $138(43.1 \%)$ & $164(51.2 \%)$ & $18(5.6 \%)$ \\
\hline Mesotherapy & $28(8.8 \%)$ & $285(89.1 \%)$ & $7(2.2 \%)$ \\
\hline Osteopathy & $14(4.4 \%)$ & $304(95.0 \%)$ & $2(0.6 \%)$ \\
\hline Prolotherapy & $6(1.9 \%)$ & $312(97.5 \%)$ & $2(0.6 \%)$ \\
\hline Ozone & $28(8.8 \%)$ & $285(89.1 \%)$ & $7(2.2 \%)$ \\
\hline Hirudotherapy & $14(4.4 \%)$ & $303(94.7 \%)$ & $3(0.9 \%)$ \\
\hline Hypnosis & $56(17.5 \%)$ & $255(79.7 \%)$ & $9(2.8 \%)$ \\
\hline Larvae Treatment & $94(29.4 \%)$ & $224(70.0 \%)$ & $2(0.6 \%)$ \\
\hline Reflexology & $45(14.1 \%)$ & $168(52.5 \%)$ & $107(33.4 \%)$ \\
\hline Music therapy & $103(32.2 \%)$ & $203(63.4 \%)$ & $14(4.4 \%)$ \\
\hline Chiropractic & $25(7.8 \%)$ & $292(91.3 \%)$ & $3(0.9 \%)$ \\
\hline
\end{tabular}

Table 3: Students' responses to the statements about TCM

\begin{tabular}{|lccc|}
\hline & I agree & No idea & I don't agree \\
\hline $\begin{array}{l}\text { Patients should consult their doctor before using } \\
\text { any TCM method. }\end{array}$ & $306(95.6 \%)$ & $10(3.1 \%)$ & $4(1.3 \%)$ \\
\hline TCM treatments are only placebo effective. & $37(11.6 \%)$ & $122(38.1 \%)$ & $161(50.3 \%)$ \\
\hline $\begin{array}{l}\text { Medical education should be TCM related } \\
\text { courses and practical training. }\end{array}$ & $253(79.1 \%)$ & $39(12.2 \%)$ & $28(8.8 \%)$ \\
\hline $\begin{array}{l}\text { TCM knowledge is important for the future } \\
\text { career of medical students. }\end{array}$ & $207(64.7 \%)$ & $68(21.3 \%)$ & $45(14.1 \%)$ \\
\hline $\begin{array}{l}\text { TCM should be a part of medicine to achieve the } \\
\text { best results in the treatment of diseases. }\end{array}$ & $212(66.3 \%)$ & $62(19.4 \%)$ & $46(14.4 \%)$ \\
\hline $\begin{array}{l}\text { Medical professionals should encourage referral } \\
\text { of patients to TCM treatments and should be } \\
\text { able to deliver them to the patient along with } \\
\text { conventional treatment. }\end{array}$ & & & \\
\hline $\begin{array}{l}\text { TCM treatment methods should only be applied } \\
\text { by physicians in health institutions. }\end{array}$ & $219(63.7 \%)$ & \\
\hline TCM: traditional and complementary medicine & & \\
\hline
\end{tabular}




\section{DISCUSSION}

Today, in parallel with the increase in the number of people utilizing TCM applications, physicians frequently encounter patients who use these methods in their daily practices and they need to direct their patients correctly in this regard. For this reason, it is important to identify the current knowledge level of medical school students, who are the physicians of the future, about traditional and complementary medicine in order to equip them with the necessary knowledge. In this study, students' knowledge, attitudes, and behavior about TCM were investigated.

In our study, acupuncture, hypnosis, and cupping were found to be the most commonly known TCM methods among medical students. In the study conducted by Sönmez et al. to evaluate the knowledge level of medical school students about TCM, the most commonly known TCM methods were found to be acupuncture, cupping, phytotherapy, hypnosis, and hirudotherapy, similar to our study. They found that the least known method was prolotherapy ${ }^{6}$. Şenol et al., in their study on medical students, found the most commonly known TCM methods to be hot spring, massage, and herbal therapy ${ }^{7}$. In the study conducted by Alzahrani et al. at a medical school in Saudi Arabia, it was found that the most commonly known methods among students were acupuncture, massage, and phytotherapy, and the least known method was homeopathy ${ }^{8}$. In the study conducted by Altan et al., it was found that the most commonly known methods among medical students were massage, phytotherapy, and meditation, and the least known method was chiropractic ${ }^{9}$. In our study, on the other hand, Prolotherapy, Reflexology, Hirudotherapy, Apitherapy, Caryopractic, and Larva Therapy were the methods that students stated they had never heard of.

In the study of Sönmez et al., 50\% of the students stated that they use a TCM method, whereas this rate was $19.1 \%$ in our study ${ }^{6}$. The most common methods used by the students in our study were cupping, leech therapy, acupuncture, phytotherapy, and hypnosis therapy. Although leech therapy was among the most commonly used methods, it was found that students' knowledge level on this subject was quite low in the questionnaire. The reason for this may be that it is not widely known as hirudotherapy, which is the name used in the literature for leech therapy. Similarly, in the study of Sonmez et al., it is seen that the most commonly used method is phytotherapy and cupping ${ }^{6}$. In the study carried out by Şenol et al., it is seen that the most commonly used method by the students is prayer, massage, and hot spring ${ }^{7}$. In the study conducted by Altan et al., they stated that phytotherapy, prayer, and massage were the methods they used the most ${ }^{9}$. The different results in other studies regarding the methods used may be due to the fact that, while planning our study, we took the 15 TCM methods defined and accepted in the Regulation on Traditional and Complementary Medicine Practices issued in 2014 as a basis. At the same time, we think that the differences are due to the fact that there was not a standardized questionnaire used in all these studies.

In our study, the most common reason for using the TCM methods was the complaints of muscle pain and common cold/flu, similar to the results of the study conducted by Sönmez et al. In the study of Sönmez et al., no side effects were observed in $88 \%$ of those who had TCM procedures, and in our study, similarly, there were no side effects in $93.4 \%{ }^{6}$. In our study, we think that the reason that all of those who had TCM procedure at a hospital were studying clinical sciences was that they are more susceptible to complications that may develop than the students studying basic sciences.

In our study, it is a striking result that the majority of the students stated that they got their information on TCM from the Internet, family, friends, and television, and only $0.9 \%$ stated that they got their information from medical education and $4.7 \%$ from healthcare workers. In other studies, conducted with medical school students in Turkey, it is similarly seen that information on TCM is reached through Internet, $\mathrm{TV}$, media, and magazines/books ${ }^{10,11,12}$. TCM-related subjects are not included in the core education program in the curriculum of medical schools, but it is known that they are included as an elective course in some faculties ${ }^{7,13}$.

The majority of the students participating in our study thought that there should be courses and practical training related to TCM in medical education. This situation is similar to the results of some studies conducted in our country and in other countries ${ }^{6,12}$. In the study of Alzahrani et al., even if the students are reluctant to have TCM subjects included in the medical education curriculum, they think that knowledge of TCM is important for their professional career ${ }^{8}$. In our study, we found that more than half of the students think that TCM knowledge is important for their future professional life.

The majority of the students (75.2\%) thought that physicians should be consulted before having a TCM procedure in the study of Alzahrani et al., 
while this rate was $95.6 \%$ in our study ${ }^{8}$. In our study, $11.6 \%$ of our students thought that TCM only had a placebo effect, whereas in the study conducted in Palestine, 35.5\% of the students were found to be of a similar opinion ${ }^{12}$. Kilıç et al., in their study carried out with Gülhane Military Medical Academy students, found that the majority of the students (64.9\%) think that TCM practices are useful in medicine. In the study of Yüksel et al., the majority of the students think that the use of TCM practices in the treatment of diseases together with modern medicine would yield better results. Like many other studies on this subject, our study contains similar results ${ }^{11,14}$.

In conclusion, we found in our study that medical school students' knowledge level of TCM practices was insufficient, and they want courses related to TCM to be included in medical education. We believe that by increasing the awareness and knowledge of medical students, who will be the health professionals of the future, about TCM in medical education, these practices can be used more beneficially and in a way that is based on evidence.

\section{Limitation}

Participation in the study was low because the questionnaire was online. However, due to the pandemic, the students were not at school and it was not possible to apply face-to-face surveys to them.

Due to the low number of participants, the comparisons (statistical analysis) were limited.

\section{REFERENCES}

1. World Health Organization. General guidelines for methodologies on research and evaluation of traditional medicine. 2000; Geneva.

2. Ünal $M$, Dağdeviren HN. Geleneksel ve Tamamlayıcı Tıp yöntemleri. Euras J Fam Med 2019; 8(1): 1-9.

3. T.C. Resmi Gazete. Geleneksel ve Tamamlayıcı Tıp Uygulamaları Yönetmeliği, 27 Ekim 2014, say1: 29158. (available from https://www.resmigazete.gov.tr/eskiler/2014/1 0/20141027-3.htm )

4. Mollahaliloğlu S, Uğurlu FG, Kalaycı MZ, Öztaş D. The new period in traditional and complementary medicine. Ankara Medical Journal 2015;15(2):102-5.

5. T. C. Resmi Gazete. Akupunktur Tedavi Yönetmeliği, 29 Mayıs 1991 Sayı No:20885 (available

from https://www.resmigazete.gov.tr/arsiv/20885.pd f) .

6. Sönmez C, Ayhan Başer D, Küçükdağ H, Kayar $\mathrm{O}$, Acar İ, Döner Güner P. Tıp fakültesi öğrencilerinin geleneksel ve tamamlayıcı tıp ile ilgili bilgi durumlarının ve davranışlarının değerlendirilmesi. Konuralp Medical Journal. 2018;10(3):276-281.

7. Şenol Y, Erdemli B, Demirezen M. Tıp fakültesi öğrencilerinin geleneksel ve tamamlayıc1 tıp hakkındaki bilgi ve davranışlarının incelenmesi. Anadolu Güncel Tip Dergisi. 2020;2(1):6-12.

8. Alzahrani SH, Bashawri J, Salawati EM, Bakarman MA. Knowledge and attitudes towards complementary and alternative medicine among senior medical students in King Abdulaziz University, Saudi Arabia. Evidence-Based Complementary and Alternative Medicine. 2016; 9370721.

9. Altan S, Rahman S, Çam S. Tıp fakültesi ögrencilerinin tamamlayıc1 ve alternatif tıp yöntemleri ile ilgili bilgi ve tutumları. Turkiye Klinikleri J Med Ethics 2014; 22: 81-8.

10. Yurtseven E, Vehid S, Bosad M, Sumer EC, Akdeniz SI, C1g G, Tahirbegolli B. Assessment of knowledge and attitudes toward Complementary and Alternative Medicine (CAM) amongst Turkish medical faculty students. African Journal of Traditional, Complementary and Alternative Medicines. 2015:12(5):8-13.

11.Kılıç S, Ogur R, Yaren H, Akkoyun NG, Küpcuk E. Bir Türk tıp okulundaki tıp öğrencilerinin tamamlayıcı ve alternatif tıp bilgisi ve tutumları. Pak J Med Sci. 2009;25(2):319-324.

12.Samara Ahmad M, Barabra ER, Quzaih HN, Zyoud SH. Use and acceptance of complementary and alternative medicine among medical students: a cross sectional study from Palestine. BMC complementary and alternative medicine. 2019;19(1):78.

13.UÇEP Çalışma Grubu. Ulusal Çekirdek Eğitim Programı-2020. Tıp Eğitimi Dünyası, 19(57-1), 1-146.

14.Yüksel NA, Aç1kgöz B, Yüksel C, Ayoğlu FN, Er T. Hekimlerin Geleneksel ve Tamamlayıcı Tıp Uygulamalarına Bakış Açısı. ESTÜDAM Halk Sağlığı Dergisi. 2019;4(3):276-86. 